DOI

\title{
ДИНАМІКА СИНДРОМУ ЕНДОГЕННОЇ ІНТОКСИКАЦІЇ В УМОВАХ ПОЛІТРАВМИ ТА ЙОГО КОРЕКЦІЯ КАРБАЦЕТАМОМ
}

\section{○Д. В. Коза \\ ДВНЗ «Тернопільський державний медичний університет імені І. Я. Горбачевського МОЗ України»}

РЕЗЮМЕ. Застосування карбацетаму з моменту виникнення політравми впродовж 14 діб в дозі 5 мг на кілограм маси тварини супроводжується істотним зниженням рівня ендогенної інтоксикації, що проявляється нормалізацією вмісту в сироватці крові фракції MCM $_{254}$ через 14-28 діб посттравматичного періоду, фракції $\mathrm{MCM}_{280}$ - через 14 і 28 діб та величини Ell - у всі терміни спостереження. В умовах застосування карбацетаму вміст у сироватці крові фракції MCM $_{254}$ через 14-28 діб, фракції MCM $_{280}$ - через 21 і 28 діб та ЕІІ - через 21 добу стає статистично вірогідно нижчим, ніж у тварин без корекції.

КЛЮчОВІ СлОВА: політравма, ендогенна інтоксикація, карбацетам.

Вступ. У патогенезі тяжкої травми синдром ендогенної інтоксикації $\epsilon$ одним із провідних механізмів. В основі його лежать гіпоксія, порушення метаболізму з накопиченням недоокиснених продуктів, посилення цитолітичних процесів, вихід в екстрацелюлярний простір протеолітичних ферментів лізосом [1, 2]. В подальшому формується синдром поліорганної дисфункції і недостатності, який замикає чергове "хибне» коло із значним накопиченням ендотоксинів, що нерідко стає причиною загибелі організму [3, 4]. Тому пошук ефективних засобів корекції синдрому ендогенної інтоксикації в умовах політравми $\epsilon$ актуальним завданням сучасної травматології.

Як показали наші попередні дослідження, у зменшенні системних проявів політравми ефективним виявився препарат з ноотропною дією карбацетам. Він зумовлював виражений антиокисдантний вплив у тканинах внутрішніх органів [5], сприяв зменшенню цитолітичного синдрому [6], забезпечував протекцію тканини печінки, серця і легень [7]. Комплексний вплив препарату не міг не торкнутися й синдрому ендогенної інтоксикації, що вимагало спеціального дослідження.

Мета роботи: з'ясувати вплив карбацетаму на динаміку синдрому ендогенної інтоксикації в умовах політравми.

Матеріал і методи дослідження. Експерименти проведено на 120 нелінійних білих щурахсамцях масою 180-200 г, які утримувалися на стандартному раціоні віварію. Тварин поділили на три групи: дві дослідних і контрольну. У дослідні групи увійшли тварини, яким в умовах тіопенталонатрієвого наркозу (40 мг на кілограм маси внутрішньоочеревинно) моделювали політравму за розробленим нами способом [8]. Контрольну групу тільки вводили у наркоз.

В першій дослідній групі протягом двох тижнів тваринам внутрішньоочеревинно вводили карбацетам (Інститут фізико-органічної хімії та вуглехімії НАН України, Донецьк) в дозі 5 мг на кілограм маси [9]. У другій дослідній групі тваринам вводили фізіологічний розчин в еквівалентній дозі.

3 експерименту тварин виводили після наркотизації шляхом тотального кровопускання із серця через 7, 14, 21 і 28 діб після травми. У крові тварин, які вижили, визначали вміст маркерів ендогенної інтоксикації- молекул середньої маси (МСМ) фракцій, які визначали при довжині хвилі 254 і 280 нм [10] та еритроцитарний індекс інтоксикації (EII) [11].

Отримані цифрові дані обробляли статистично. Вірогідність відмінностей між дослідними і контрольною групами оцінювали з використанням програми STATISTICA ("StatSoft, Inc.», США).

Результати й обговорення. Як видно з таблиці 1, в умовах політравми вміст у сироватці крові фракції МСM $_{254}$ суттєво зростав, порівняно із контрольною групою, і був через 7 діб більшим на $38,8 \%$, через 21 добу - на 26,4 \%, через 28 діб - на $6,8 \%(p<0,05)$. Через 14 діб показник ставав суттєво меншим від контрольної групи (на 9,0\%, p<0,05). Після застосування карбацетаму показник виявився істотно вищим від контролю тільки через 7 діб (на $28,2 \%, p<0,05$ ). У наступні терміни посттравматичного періоду величина цього показника досягала рівня контролю та істотно від нього не відрізнялася $(p>0,05)$. При цьому в усі терміни спостереження введення карбацетаму супроводжувалося меншим вмістом фракції MCM $_{254}$ у сироватці крові, ніж у групі тварин без корекції (на р<0,05).

Вміст у сироватці крові фракції МСМ $_{280}$ в умовах політравми через 7, 21 і 28 діб істотно перевищував рівень контрольної групи (відповідно на 48,2, 64,4 і 22,6 \%, p<0,05). Як і попередній показник, вміст у сироватці крові фракції MCM $_{280}$ через 14 діб ставав істотно меншим від контролю - на $12,6 \%, p<0,05)$. Під впливом карбацетаму показник змінювався хвилеподібно: з 7 до 14 доби він 
Огляди літератури, оригінальні дослідження, погляд на проблему

Таблиця 1. Порушення показників ендогенної інтоксикації у відповідь на політравму та ефективність корекції карбацетамом (M $\pm \mathrm{m})$

\begin{tabular}{|c|c|c|c|c|c|c|}
\hline \multirow[b]{2}{*}{ Показник } & \multirow[b]{2}{*}{ Група } & \multirow[b]{2}{*}{$\begin{array}{c}\text { Контроль } \\
(n=20)\end{array}$} & \multicolumn{4}{|c|}{ Доба посттравматичного періоду } \\
\hline & & & $\begin{array}{c}7 \\
(n=6 / 6)\end{array}$ & $\begin{array}{c}14 \\
(n=6 / 6)\end{array}$ & $\begin{array}{c}21 \\
(n=6 / 6)\end{array}$ & $\begin{array}{c}28 \\
(n=5 / 5)\end{array}$ \\
\hline \multirow{2}{*}{$\begin{array}{l}\text { MCM }_{254 \prime} \\
\text { ум. од. }\end{array}$} & Політравма & \multirow[b]{2}{*}{$405,5 \pm 5,0$} & $562,7 \pm 5,5^{*}$ & $369,0 \pm 8,2^{*}$ & $512,7 \pm 14,8^{*}$ & $433,2 \pm 8,8^{*}$ \\
\hline & $\begin{array}{c}\text { Політравма+ } \\
\text { карбацетам }\end{array}$ & & $520,0 \pm 8,3^{*}$ & $410,5 \pm 9,0$ & $442,3 \pm 15,2$ & $380,8 \pm 14,5$ \\
\hline \multicolumn{3}{|c|}{$\mathrm{p}$} & $<0,05$ & $<0,05$ & $<0,05$ & $<0,05$ \\
\hline \multirow[b]{2}{*}{$\begin{array}{l}\text { МСM }_{280^{\prime}} \\
\text { ум. од. }\end{array}$} & Політравма & \multirow[b]{2}{*}{$201,0 \pm 2,5$} & $298,0 \pm 7,4^{*}$ & $175,7 \pm 6,3^{*}$ & $330,5 \pm 12,6^{*}$ & $246,4 \pm 6,1^{*}$ \\
\hline & $\begin{array}{c}\text { Політравма+ } \\
\text { карбацетам }\end{array}$ & & $260,7 \pm 11,8^{*}$ & $190,5 \pm 11,7$ & $259,0 \pm 9,2^{*}$ & $214,8 \pm 8,2$ \\
\hline \multicolumn{3}{|c|}{$p$} & $<0,05$ & $>0,05$ & $<0,05$ & $<0,05$ \\
\hline \multirow{2}{*}{$\begin{array}{c}\text { Ell, } \\
\%\end{array}$} & Політравма & \multirow[b]{2}{*}{$44,15 \pm 0,85$} & $43,91 \pm 1,49$ & $41,20 \pm 1,79$ & $48,35 \pm 1,55^{*}$ & $41,40 \pm 0,86$ \\
\hline & $\begin{array}{c}\text { Політравма+ } \\
\text { карбацетам }\end{array}$ & & $46,47 \pm 1,69$ & $40,25 \pm 1,44^{*}$ & $42,37 \pm 1,40$ & $40,12 \pm 1,69^{*}$ \\
\hline \multicolumn{3}{|c|}{$p$} & $>0,05$ & $>0,05$ & $<0,05$ & $>0,05$ \\
\hline
\end{tabular}

Примітки:

1. * - вірогідність відмінностей стосовно контрольної групи $(p<0,05)$.

2. p - вірогідність відмінностей між групами лікованих і нелікованих тварин.

3. $n$ - у чисельнику кількість тварин у групі щурів з політравмою, у знаменнику кількість тварин у групі щурів з політравмою, корегованих карбацетамом.

знижувався. При цьому через 7 діб він був істотно більшим від контролю (на 29,7 \%, р<0,05) та меншим, ніж у групі тварин без корекції (на 12,5 \%, p<0,05). Через 14 діб показник нормалізувався і вірогідно від контролю не відрізнявся $(p>0,05)$. Через 21 добу наставала друга хвиля його зростання: на 28,9\% він ставав більшим від контролю і на 36,0 \% - від рівня попереднього терміну спостереження $(p<0,05)$. Через 28 діб показник знову знижувався і досягав величини контрольної групи (р>0,05). При цьому через 21 і 28 діб вміст у сироватці крові фракції МСМ 280 статистично вірогідно був меншим, ніж у групі тварин без корекції (відповідно, на 21,6 і 12,8 \%, p<0,05).

Величина Ell в умовах політравми статистично вірогідно перевищувала рівень контрольної групи тільки через 21 добу (на 9,5\%, p<0,05). В інші терміни показник від контролю істотно не відрізнявся ( $>>0,05)$. Під впливом карбацетаму величина Ell через 7 діб перебувала на рівні контрольної групи, проте через 14 діб ставала істотно нижчою $(p<0,05)$. Через 21 добу показник знову досягав рівня контролю, а через 28 діб повторно зменшувався, що було статистично вірогідним стосовно контрольної групи $(p<0,05)$. При цьому через 21 добу величина Ell у групі щурів, які отримували карбацетам, ставала статистично вірогідно меншою, ніж у групі тварин без корекції (на $12,4 \%$, p<0,05).

Таким чином, під впливом політравми в термін 37 до 28 діб достатньо високим залишається рівень ендогенної інтоксикації з періодом тимчасового благополуччя через 14 діб, що відмічалося в наших попередніх дослідженнях [12]. Застосування карбацетаму супроводжується істотним зниженням рівня ендогенної інтоксикації, що проявляється нормалізацією вмісту в сироватці крові фракції МСM $_{254}$ через 14-28 діб посттравматичного періоду, фракції МСМ 280 - через 14 і 28 діб та величини Ell - у всі терміни спостереження. При цьому останній показник через 14 і 28 діб стає меншим від рівня контролю. Привертає увагу той факт, що вміст у сироватці крові фракції MCM $_{254}$ через 14-28 діб, фракції MCM $_{280}$ - через 21 і 28 діб та EII - через 21 добу є статистично вірогідно нижчим, ніж у тварин без корекції. Отже, для карбацетаму, крім цитопротекторного, антиоксидантного та мембраностабілізувального впливів, характерна й детоксикаційна дія, що очевидно, пов'язано із його впливом на ключові первинні ланки патогенезу травматичної хвороби - підвищення стійкості до гіпоксії та антиоксидантний вплив, що притаманно для препаратів з ноотропною дією [13]. Отримані результати націлюють на перспективність застосування карбацетаму в інтенсивній терапії синдрому ендогенної інтоксикації при тяжкій травмі.

Висновки. 1. Застосування карбацетаму 3 моменту виникнення політравми впродовж 14 діб в дозі 5 мг на кілограм маси тварини супроводжується істотним зниженням рівня ендогенної інтоксикації, що проявляється нормалізацією вмісту в сироватці крові фракції MCM $_{254}$ через 14-28 діб посттравматичного періоду, фракції $\mathrm{MCM}_{280}$ - через 14 і 28 діб та величини Ell - у всі терміни спостереження.

2. В умовах застосування карбацетаму вміст у сироватці крові фракції МСM $_{254}$ через $14-28$ діб, фракції MCM $_{280}$ - через 21 і 28 діб та Ell - через 21 
Огляди літератури, оригінальні дослідження, погляд на проблему

добу стає статистично вірогідно нижчим, ніж у тварин без корекції.

Перспективи подальших досліджень. В перспективі доцільним напрямком є комплексне дослідження системного корегувального впливу карбацетаму на різних моделях травматичної хвороби.

\section{ЛІТЕРАТУРА}

1. Избранные аспекты патогенеза и лечения травматической болезни / В. Н. Ельский, В. Г. Климовицкий, С. Е Золотухин [и др.] - Донецк : ООО «Лебедь», 2002. $360 \mathrm{c}$.

2. Особенности изменений активносты оксиредуктаз, содержания малонового диальдегида и молекул средней массы в крови больных с черепно-мозговой травмой различной степени тяжести / Д. Е. Иванов, Д. М. Пучиньян, В. Г. Нинель [и др.] // Клин. лаб. діагностика. - 2001. - № 5. - С. 40-41.

3. Ранняя диагностика синдрома полиорганной дисфункции у пострадавших с политравмой / С. В. Гайдук, В. В. Бояринцев, С. В. Гаврилин [и др.] // «Политравма: диагностика, лечение и профилактика осложнений». Материалы II Всероссийской научно-практической конференции. - Ленинск-Кузнецкий, 2007. - С. 40.

4. Эндотоксикоз при тяжелой сочетанной травме / И. А. Ерюхин, С. В. Гаврилин, Н. С. Немченко [и др.] // Вестн. хирургии. - 2001. - Т. 160, № 5. - С. 120-124.

5. Козак Д. В. Вплив карбацетаму на антиоксидантний-прооксидантний баланс тканини серця, легень і печінки в динаміці політравми / Д. В. Козак // Шпитальна хірургія. - 2014. - № 1 (65). - С. 40-42.

6. Козак Д. В. Вплив карбацетаму на динаміку показників цитолізу та вміст циркулюючих імунних комплексів в умовах політравми / Д. В. Козак // Вісник наукових досліджень. - 2014. - № 2 (75). - С. 80-82.

7. Козак Д. В. Структурні зміни деяких внутрішніх органів тварин із модельованою політравмою за умов корекції карбацетамом / Д. В. Козак, К. С. Волков // Науковий вісник Ужгородського університету, серія «Медицина». - 2014. - Вип. 2 (50). - С. 3-6.

8. Пат. 63997 Україна, МПК G 09 В 23/28. Спосіб моделювання політравми / Козак Д. В.; заявник і патентовласник Тернопільський державний медичний університет імені І. Я. Горбачевського. - № ч 201104110 ; заявл. 05.04.11; опубл. 25.10.11, Бюл. 20.

9. Комиссаров И. В. Коррекция лигандами глутаматных рецепторов нарушений мнестических функций при экспе-риментальной фокальной ишемии коры мозга / И. В. Комиссаров, А. В. Журавский, В. Е. Гмиро // Журнал АМН України. - 2003. Т. 9, № 2. - С. 238-249.

10. Методи дослідження ендогенної інтоксикації організму : методичні рекомендації / М. А. Андрейчин, М. Д. Бех, В. В. Дем'яненко [та ін.]. - К., 1998. - С. 10-13.

11. Способ диагностики эндогенной интоксикации / А. А. Тогайбаев , А. В. Кургузкин , Р. М. Рикун, Р. М. Крибжанова // Ла6. дело. - 1988. - Т. 4, № 9. - С. 22-24.

12. Kozak D. V. Lipid peroxidation, antioxidant defence, endogenous intoxication and cytolysis variations in early and late manifestations of traumatic disease / D. V. Kozak // Journal of Health Sciences. - 2013. - Vol. 3, № 4. - P. 108-117.

13. Бурчинский С. Г. Нейропротекция как комплексная фармакотерапевтическая и фармакопрофилактическая стратегия / С. Г. Бурчинский // Theгаріа. 2008. - № 2. - C. 5-8.

\section{DYNAMICS OF SYNDROME ENDOGENOUS INTOXICATION UNDER CONDITIONS OF POLYTRAUMA AND CORRECTION OF CARBACETAM}

\section{SHEI «Ternopil State Medical University by I. Ya. Horbachevsky of MPH of Ukraine»}

SUMMARY. Application Carbacetam from the date of trauma for 14 days at a dose of $5 \mathrm{mg}$ per kilogram of animal is accompanied by a significant reduction in endogenous intoxication, which is manifested in normalization of serum fractions MMM254 through 14-28 days post-traumatic period faction MMM280 - after 14 and 28 days and Ell value - in all terms of observation. In terms of application Carbacetam content in blood serum fractions 14-28 days via MMM280, MMM254 faction - after 21 and 28 days and Ell - 21 days is statistically significantly lower than in animals without correction.

KEY WORDS: polytrauma, endogenous intoxication, Carbacetam. 